Provided for non-commercial research and education use. Not for reproduction, distribution or commercial use.

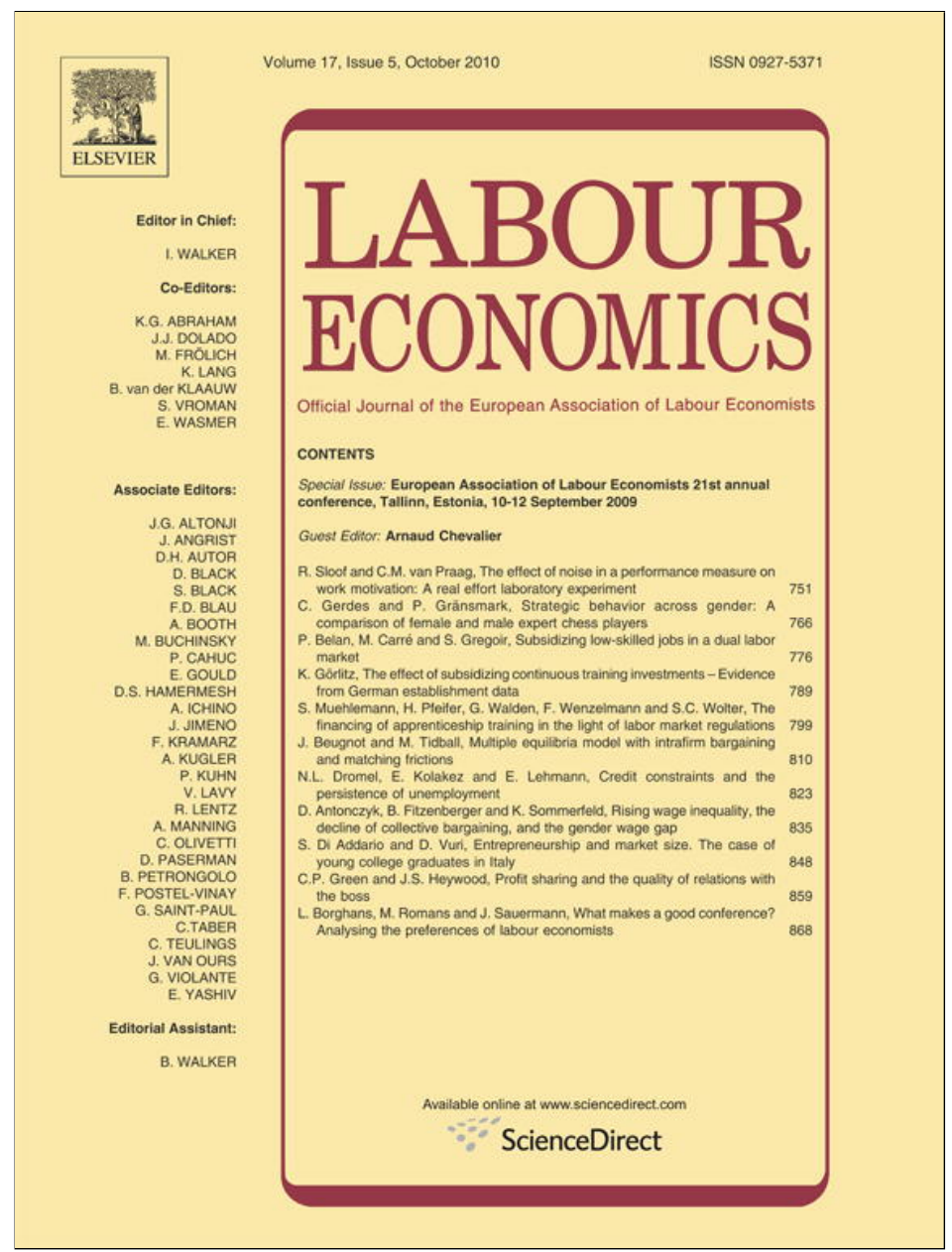

This article appeared in a journal published by Elsevier. The attached copy is furnished to the author for internal non-commercial research and education use, including for instruction at the authors institution and sharing with colleagues.

Other uses, including reproduction and distribution, or selling or licensing copies, or posting to personal, institutional or third party websites are prohibited.

In most cases authors are permitted to post their version of the article (e.g. in Word or Tex form) to their personal website or institutional repository. Authors requiring further information regarding Elsevier's archiving and manuscript policies are encouraged to visit:

http://www.elsevier.com/copyright 


\title{
Entrepreneurship and market size. The case of young college graduates in Italy
}

\author{
Sabrina Di Addario ${ }^{\mathrm{a}, *}$, Daniela Vuri ${ }^{\mathrm{b}}$ \\ a Bank of Italy, Italy \\ ${ }^{\mathrm{b}}$ University of Rome Tor Vergata, Italy
}

\section{A R T I C L E I N F O}

\section{Article history:}

Received 15 October 2009

Received in revised form 10 April 2010

Accepted 13 April 2010

Available online 28 April 2010

\section{JEL classification:}

R12

$\mathrm{J} 24$

J21

\section{Keywords:}

Labour market transitions

Urbanization

\begin{abstract}
A B S T R A C T
We analyse empirically the effects of urbanization on Italian college graduates' work possibilities as entrepreneurs three years after graduation. We find that doubling the province of work's population density reduces the chances of being an entrepreneur by 2-3 percentage points. This result holds after controlling for regional fixed effects and is robust to instrumenting urbanization. Provinces' competition, urban amenities and dis-amenities, cost of labour, earning differentials between employees and self-employed workers, unemployment rates and value added per capita account for more than half of the negative urbanization penalty. Our result cannot be entirely explained by the presence of negative differentials in returns to entrepreneurship between the most and the least densely populated areas. In fact, as long as they succeed in entering the most densely populated markets, young entrepreneurs are able to reap-off the benefits of urbanization externalities: the elasticity of entrepreneurs' net monthly earnings with respect to population density is $0.02-0.03$.
\end{abstract}

(c) 2010 Elsevier B.V. All rights reserved.

\section{Introduction}

The literature on agglomeration has mainly studied the impact of urbanization economies (i.e., the externalities arising from the level of cities' economic activities as a whole but external to specific industries $)^{1}$ on firms rather than on entrepreneurs. According to the theory, urbanization externalities encourage firm location in the most densely populated markets, where productivity is highest (see, for instance, Ciccone and Hall (1996), Ciccone (2002) and Moomaw, 1983), the expected quality of employer-employee match is best (Helsley and Strange (1990), Kim, 1990), search costs per worker are lowest (Wheeler, 2001), and learning, the diffusion of technological spillovers and the acquisition of entrepreneurial capabilities are fastest (see Guiso and Schivardi (2007) and Rosenthal and Strange (2004) for a review of the literature). However, after a certain threshold congestion dis-externalities prevail over agglomeration economies, and some sort of selection into the densest markets is needed. Firms might be selected on the basis of their order of arrival (e.g., Helsley and Strange, 1990), productivity (like in Behrens and Robert-Nicoud, 2008), Darwinian selection (Melitz and Ottaviano, 2008), the extent they benefit from forward-backward linkages

* Corresponding author. Economic Research Unit, Branch of Rome, Bank of Italy, via XX settembre, 97/e, 00187, Rome, Italy. Tel.: +39 064792 3458; fax: +39 064792 5351.

E-mail addresses: sabrina.diaddario@bancaditalia.it (S. Di Addario),

${ }^{1}$ As opposed to localization economies, internal to each industry (Henderson, 1983).
(Baldwin and Okubo, 2006), or simply on the basis of their sector (Henderson (1983), LaFountain, 2005).

In contrast to the majority of the agglomeration literature, we estimate urbanization effects on entrepreneurs rather than firms or employees. In particular, we examine whether population density in the individual's province of work increases the probability of being an entrepreneur and/or creates urban differentials in the returns to entrepreneurship. While firm type (e.g., sector, size, etc.) is certainly a determinant of location, as some sectors depend more on scale, urban amenities and local endowment of natural resources than others, entrepreneurs' characteristics (e.g., ability, education, experience, age) may also matter.

To this purpose we use a unique data set provided by the Italian National Institute of Statistics (ISTAT), examining college-to-work transitions three years after graduation. Although college graduates represent just about $11 \%$ of Italian entrepreneurs, using this data source has the advantage of providing a homogeneous sample of individuals facing similar work choices (i.e., college graduates at the same stage of the life cycle). Moreover, focusing on college graduates minimizes the probability of including 'out of necessity' entrepreneurs in our sample, since the individuals choosing selfemployment because of lack of outside options are generally the least educated workers (the 'ability-bias' hypothesis). Several studies have shown that the ability-bias can be quite important: in the US, for instance, up to $10 \%$ of the entrepreneurs becomes such because of lack of suitable alternatives rather than in order to pursue an opportunity (see Poschke (2008), Lazear, 2005). Another advantage of our data set is that the limited mobility of labour in Italy reduces the likelihood that our urbanization estimates are 
biased by sorting into the most densely populated provinces (i.e., entrepreneurs with unobserved characteristics correlated to work choices moving into the most densely populated markets). Indeed, according to ISTAT (ISTAT, 2003) in Italy more than $80 \%$ of individuals with live parents reside in the same municipality as their mothers' or fathers', about $7 \%$ of the people live in a municipality within $16 \mathrm{~km}$ from their parents', and only $8.2 \%$ of the citizens reside abroad or at a distance greater than $50 \mathrm{~km}$. Besides cultural reasons (see, for instance, Alesina et al., 2010), the strong family ties in Italy are due to the lack of a good welfare system, leaving parental care largely to offspring and child care to grandparents. However, entrepreneurs have further reasons to live close to their place of origin, as they might be willing to exploit the local family networks to start their business (personal contacts and customer base). Michelacci and Silva (2007), for instance, show both that in Italy and the US entrepreneurs are more likely to obtain bank credit when the firm is local and that the probability of working in the province of birth is higher for entrepreneurs (whether or not start-ups) than for employees. This result is in line with Blanchflower (2000), who finds that in most OECD countries self-employed workers are less willing to move from their neighbourhood, town or region than employees. In particular, Italy is the OECD country among the 23 analysed in his paper with the least willing-to-move self-employed individuals. In Italy mobility is surprisingly limited also among students, who are generally one of the most mobile segment of the population, even in the areas endowed with low-quality universities (e.g., the South). Indeed, according to Brunello and Cappellari (2008) almost three quarters of the Southern students graduates in the South, but just $8 \%(20 \%)$ of them moves to the North (Centre), in spite of the fact that individuals graduating in a Northern faculty earn higher employment-weighted wages than those graduating in a Southern faculty. ${ }^{2}$

We define as 'entrepreneurs' all the individuals who either describe themselves as such or as members of the arts and professions during the interview (see Section 2 for further details). Contrary to the predictions of the literature on agglomeration, we find that, other things being equal, three years after graduation college graduates are more likely to start an activity of their own in the least than in the most densely populated provinces. In particular, doubling the province of work's population density reduces the probability of being an entrepreneur by about 2-3 percentage points. This penalty persists after instrumenting urbanization with population density in 1921. We then investigate whether our finding can be explained by across-province differentials in competition, urban amenities and dis-amenities, labour costs, outside options, unemployment rates, and value added per capita. Our results indicate that overall these province characteristics account for more than half of the negative urbanization effect. Finally, we investigate whether the sign of our urbanization outcome can be explained by the presence of negative differentials in returns to entrepreneurship between the most and the least densely populated markets, similarly to Di Addario and Patacchini (2008) and de Blasio and Di Addario (2005), who find that the most highly educated employees earn relatively less in the urban or industrially agglomerated areas than elsewhere in Italy, in contrast to the least educated workers. In fact, we find that returns to entrepreneurship increase with population density: the elasticity of young entrepreneurs' net monthly earnings with respect to the province of work's population density is $0.02-0.03$.

This last result, in line with the literature, predicting that agglomeration externalities increase productivity in the most

\footnotetext{
${ }^{2}$ The authors ascribe the low student mobility to North-South cost differentials (university fees, rents, etc.), rather than to the existence of financial constraints. According to Makovec (2006), Southerners graduating in the North earn $25 \%$ more than those who stay and $6 \%$ more than those who move to the North after graduation.
}

densely populated markets (for evidence on Italy see, for instance, Cingano and Fabiano (2004) and Guiso and Schivardi, forthcoming), poses an apparent puzzle: why is it less likely to become entrepreneurs in the densest provinces, given that returns to entrepreneurship increase with population density? A possible explanation of this puzzling result is that the least densely populated markets easy entrepreneurship by reducing the costs of firm setting up. Indeed, we find that the presence of local banks, inversely correlated with population density, increases the likelihood of becoming entrepreneur three years after graduation, implying that entry costs are an important determinant in young college graduates' work decisions. Conversely, we obtain that entry into the most densely populated markets is particularly difficult for young entrepreneurs, especially because of tougher competition.

The paper is organized as follows. The next section describes the data and provides descriptive statistics. Section 3 presents the econometric results and the robustness checks; Section 4 tests alternative hypotheses potentially explaining our results; Section 5 investigates whether there are earning differentials, and the last one concludes.

\section{The data}

The main data source of this paper is the Survey on the Early Career of College Graduates (SECCG, "Indagine sull'inserimento professionale dei laureati") conducted by ISTAT every three years. We analyse the individuals graduated in 1995, 1998 and 2001, and interviewed, respectively, in 1998, 2001 and 2004. In the first semester of each survey year ISTAT extracts a random sample (about 16\% of the total) from the universe of the individuals graduating in that year, stratified on the basis of gender, faculty and university. In the second semester ISTAT interviews the sampled individuals by phone, double-checking all answers with universities' administrative records. Among the Italian surveys currently available, SECCG offers the most precise and detailed information on demographic characteristics, college attended, ability, family background, current employment and income of recently graduated individuals. The survey also collects information on the province of work, enabling us to compute the impact of urbanization on the probability of transition from university into entrepreneurship. To compute the urbanization variable, we merge our data set with the Census' population density by year of interview and province of work (the finest disaggregation available in the survey). Our sample is distributed in all the 103 Italian provinces. We complement the data base with other variables at the provincial level drawn from various sources (described in the Appendix).

Our sample, consisting of 33,740 college graduates, has been obtained after excluding: the more-than-35 year-old individuals, foreigners, Italians working abroad, the agricultural-sector workers, and the non-employed people. Moreover, we exclude individuals who were already employed in the current job before graduating because we intend to focus on work choices after graduation, and the former might be a selected sample of the working population.

Seventeen percent of our sampled individuals are an entrepreneur (Table 1). In addition to the individuals strictly identifying themselves as such, our definition of entrepreneur includes professionals and excludes the members of a family business, similarly to Michelacci and Silva (2007). Indeed, like entrepreneurs, the members of the arts and professions take decisions independently and are risk-bearing, since they are personally liable for their business activity. Conversely, family business members are often not involved in decision making and do not necessarily share the risk with the firm owner. Unlike Michelacci and Silva, we exclude managers (as we do not have this piece of information) and craftsmen, because in Italy, where the pressure of taxation and employees' contributions is high, the recorded information on this 
type of self-employment category might be measured with error for its greater facility to evade taxes. Our definition also excludes the so-called co.co.co (free-lance workers) because they generally perform the same tasks as employees, in spite of the fact that they are considered self-employed by ISTAT (because they have no guarantees as payroll employees).

To analyse the differences in our variables' distribution between the most and the least densely populated markets, we provide the descriptive statistics for the total sample, the individuals working in the top 10th percentile of Italian provinces' population density distribution, and those employed in the rest of the country (Table 1). As expected, a larger share of entrepreneurs and employees works in the most densely populated areas than elsewhere (respectively, 16 and $71 \%$ against 15 and $65 \%$ in the least dense markets), while there is no difference in the spatial distribution of the other categories of self-employed workers. Moreover, monthly earnings from entrepreneurship are $10.0 \%$ higher in the most densely populated provinces than in the rest of the country. The least densely populated provinces exhibit a slightly higher share of women and older people than the densest ones. Provinces also differ with respect to the type of school attended: students choose more frequently lyceums in the most densely populated areas, and surveyor or teacher schools in the least dense markets. College graduates obtain higher final grades, on average, in the least densely populated provinces, though a higher percentage of individuals graduates on time in the densest markets than elsewhere. The share of college graduates who hold a Ph.D. does not vary across provinces of different density levels. In line with the literature, human capital-intensity is positively correlated with population density: the share of individuals whose parents have a secondary education or a college degree is higher in the most than in the least densely populated provinces, while the share of parents with a primary or middle school attainment is lower. The densest markets also exhibit a higher share of self-employed workers' offspring than elsewhere, suggesting that intergenerational persistence is positively correlated with population density.

With respect to the variables at the provincial level, urban disamenities (i.e., house prices) and competition (i.e., the share of selfemployed workers in the individual's sector) are higher in the most densely populated markets than in the rest of the country. In contrast, but in line with literature, the share of local banks is negatively correlated with population density. In particular, $40 \%$ (29\%) of the banks in the least (most) densely populated markets is local.

\section{Results}

\subsection{Chances of being an entrepreneur}

The descriptive statistics reported in Table 1 show that the share of recently graduated entrepreneurs is 1 percentage point higher in the most densely populated provinces than in the rest of the country, in line with the predictions of the agglomeration theory. In this section we test empirically whether this result holds after controlling for individual characteristics. In particular, we estimate the impact of population density on the likelihood of being an entrepreneur three years after graduation. We use a probit model and correct the standard errors for the possibility that the residuals are interdependent at the provincial level (33,740 observations distributed in three time periods over 103 provinces provide our estimations with enough degrees of freedom; see Card, 2001). Using repeated crosssectional data, we estimate the following equation on the sample of employed individuals:

$$
\operatorname{Prob}\left(\text { Entrepr }_{i j t}=1\right)=\alpha+\Sigma \beta X_{i j t}+\delta D E N_{j t}+\gamma R F E_{j}+\lambda t+u_{i j t},
$$

where Entrepr $r_{i j t}$ is a dummy variable equal to one if the individual $i$ working in province $j$ and interviewed at time $t$ is an entrepreneur; DEN is the province of work's population density (our urbanization variable), $X$ indicates the personal observable characteristics, $t$ the year-of-interview dummies, and RFE the region-specific fixed effects, capturing, for instance, the impact of local taxes or the presence of natural advantage or amenities (see Ciccone (2002) and Rosenthal and Strange, 2003).

The first column of Table 2 shows our basic specification, including sex, age, education, civil status and number of siblings as individual characteristics. In the second column $((2.2))$ we add the secondary school and faculty-group attended, because some types of training are better suited for entrepreneurship than others. In column (2.3) we include the effect of intergenerational persistence with two dummy variables equal to one if the individual's father and/or mother are/were self-employed. We also add a proxy of family networks (equal to one if the individual found the job or started his/her activity through the help of relatives or friends, zero otherwise), which might easy access to entrepreneurship through personal and business contacts or customer base (Blanchflower, 2000). In the same specification we also control for parents' education level. In column (2.4) we add a few proxies for ability (grade obtained at college, a dummy for graduating with honours, and a variable equal to one if the student graduated on time) and two variables denoting whether the individual was working - occasionally or continuously - while studying. Finally, in specification (2.5) we add individuals' work experience (number of months worked) and sector of employment, because some industries require a larger amount of initial capital than others (see, for instance, Rajan and Zingales, 1998).

Results indicate that doubling the province of work's population density lowers the chances of being entrepreneur by $2-3$ percentage points. This result is stable across all the specifications (columns (2.1)-(2.5)) and always significant at the $1 \%$ statistical level. ${ }^{3}$

When analysing some of the other covariates, we find that women are less likely of becoming entrepreneurs. In contrast, age and being married increase the chances of entrepreneurship, while having a Ph.D. degree does not have any effect. This result is not surprising because in Italy very few college graduates enrol and complete a Ph.D. three years after graduation (just $0.2 \%$ of our sampled individuals). Having attended the science, chemistry, humanities and foreign languages faculties lowers the likelihood of starting an activity of one's own, while attending the majority of the remaining colleges (e.g., engineering, architecture, agriculture, law) and vocational schools (specialized in industrial subjects) increases it. Most importantly, we find evidence of intergenerational persistence: having a self-employed father or mother increases the probability of becoming entrepreneur. Moreover, the family network proxy increases the chances of entrepreneurship, as expected. In contrast, final grade at college and the honour dummy are non-significant, while having graduated on time is significantly positive. The non-significance of the former might be due to the fact that cognitive ability does not fully capture the capabilities required to become entrepreneurs (though many empirical papers proxy entrepreneurial ability just with education; e.g., Poschke (2008), Le (1999) and Calvo and Wellisz, 1980). Indeed, being an entrepreneur has probably more to do with being multifaceted (i.e., well versed in various fields, able to perform a large number of different tasks and

\footnotetext{
${ }^{3}$ We also tested whether our results hold when measuring urbanization with the province's density of college graduates (rather than with overall population density). Indeed, it might be the case that college graduates' productivity increases more with proximity to other highly educated workers than with vicinity to low skilled people (see Rosenthal and Strange, 2008), because graduate entrepreneurs might have more to learn from nearby human capital. Nevertheless, the results of this exercise (available on request) remain unchanged with respect to those reported in Table 2. Thus, our findings are not sensitive to the choice of the population of reference.
} 
Table 1

Summary statistics.

\begin{tabular}{|c|c|c|c|c|c|c|}
\hline & \multicolumn{2}{|c|}{ All sample } & \multicolumn{2}{|c|}{ Densest provinces } & \multicolumn{2}{|c|}{ Rest of the country } \\
\hline & Mean & St.dev & Mean & St.dev & Mean & St.dev \\
\hline Employees*** & 0.67 & 0.47 & 0.71 & 0.45 & 0.65 & 0.48 \\
\hline Entrepreneurs*** & 0.17 & 0.38 & 0.16 & 0.36 & 0.15 & 0.36 \\
\hline Self-employed (except for entrepreneurs) & 0.16 & 0.36 & 1100.42 & 436.29 & 1000.75 & 455.19 \\
\hline Monthly wage from entrepreneurship $\dagger^{* * *}$ & 1037.00 & 450.95 & 1089.46 & 449.11 & 995.72 & 448.12 \\
\hline \multicolumn{7}{|l|}{ Personal characteristics } \\
\hline Female ${ }^{* * *}$ & 0.50 & 0.50 & 0.49 & 0.50 & 0.51 & 0.50 \\
\hline Married $^{* * *}$ & 0.19 & 0.39 & 0.17 & 0.38 & 0.20 & 0.40 \\
\hline Age $^{* * *}$ & 29.57 & 2.01 & 29.42 & 1.94 & 29.65 & 2.03 \\
\hline Ph.D. degree & 0.00 & 0.05 & 0.00 & 0.04 & 0.00 & 0.05 \\
\hline Number of siblings* & 1.25 & 0.88 & 1.23 & 0.86 & 1.26 & 0.89 \\
\hline \multicolumn{7}{|l|}{ High school characteristics } \\
\hline Lyceum*** & 0.64 & 0.48 & 0.69 & 0.46 & 0.61 & 0.49 \\
\hline Teachers' training school ${ }^{* * *}$ & 0.05 & 0.21 & 0.03 & 0.18 & 0.05 & 0.23 \\
\hline School for surveyors $* * *$ & 0.28 & 0.45 & 0.25 & 0.43 & 0.30 & 0.46 \\
\hline Vocational school & 0.03 & 0.17 & 0.03 & 0.17 & 0.03 & 0.18 \\
\hline \multicolumn{7}{|l|}{ Type of degree } \\
\hline Chemistry-pharmaceutical*** & 0.07 & 0.25 & 0.05 & 0.23 & 0.08 & 0.27 \\
\hline Biology and geology*** & 0.05 & 0.22 & 0.04 & 0.20 & 0.05 & 0.23 \\
\hline Science $^{* * *}$ & 0.06 & 0.24 & 0.07 & 0.25 & 0.06 & 0.24 \\
\hline Medicine*** $^{* *}$ & 0.04 & 0.20 & 0.03 & 0.18 & 0.04 & 0.21 \\
\hline Engineering*** & 0.19 & 0.40 & 0.22 & 0.41 & 0.19 & 0.39 \\
\hline Architecture & 0.05 & 0.22 & 0.05 & 0.22 & 0.05 & 0.21 \\
\hline Agriculture ${ }^{* * *}$ & 0.03 & 0.16 & 0.02 & 0.14 & 0.03 & 0.17 \\
\hline Economics and statistics ${ }^{* * *}$ & 0.19 & 0.39 & 0.22 & 0.41 & 0.18 & 0.38 \\
\hline Political and social science *** $^{* *}$ & 0.06 & 0.24 & 0.07 & 0.26 & 0.05 & 0.22 \\
\hline Law $^{* * *}$ & 0.08 & 0.27 & 0.07 & 0.26 & 0.08 & 0.27 \\
\hline Humanities ${ }^{* * *}$ & 0.07 & 0.25 & 0.06 & 0.23 & 0.07 & 0.26 \\
\hline Foreign languages*** & 0.05 & 0.22 & 0.05 & 0.21 & 0.05 & 0.23 \\
\hline Teaching*** & 0.03 & 0.17 & 0.02 & 0.14 & 0.03 & 0.18 \\
\hline Psychology** & 0.03 & 0.16 & 0.03 & 0.17 & 0.03 & 0.16 \\
\hline \multicolumn{7}{|l|}{ Father's education } \\
\hline Primary education ${ }^{* * *}$ & 0.17 & 0.38 & 0.13 & 0.34 & 0.20 & 0.40 \\
\hline Middle school ${ }^{* * *}$ & 0.24 & 0.43 & 0.22 & 0.42 & 0.26 & 0.44 \\
\hline High school ${ }^{* * *}$ & 0.36 & 0.48 & 0.39 & 0.49 & 0.34 & 0.47 \\
\hline College degree ${ }^{* * *}$ & 0.22 & 0.41 & 0.25 & 0.43 & 0.20 & 0.40 \\
\hline \multicolumn{7}{|l|}{ Mother's education } \\
\hline Primary education ${ }^{* * *}$ & 0.23 & 0.42 & 0.18 & 0.38 & 0.26 & 0.44 \\
\hline Middle school ${ }^{* * *}$ & 0.27 & 0.45 & 0.26 & 0.44 & 0.28 & 0.45 \\
\hline High school ${ }^{* * *}$ & 0.35 & 0.48 & 0.38 & 0.49 & 0.33 & 0.47 \\
\hline College degree ${ }^{* * *}$ & 0.15 & 0.35 & 0.17 & 0.38 & 0.13 & 0.34 \\
\hline \multicolumn{7}{|l|}{ Parents' occupational status } \\
\hline Self-employed father*** & 0.08 & 0.27 & 0.08 & 0.28 & 0.07 & 0.26 \\
\hline Self-employed mother*** & 0.01 & 0.10 & 0.01 & 0.11 & 0.01 & 0.09 \\
\hline \multicolumn{7}{|l|}{ Ability proxies } \\
\hline Final grade at college $e^{* * *}$ & 103.01 & 7.04 & 102.81 & 7.30 & 103.18 & 6.84 \\
\hline Laude & 0.21 & 0.40 & 0.21 & 0.41 & 0.20 & 0.40 \\
\hline Graduated on time*** & 0.15 & 0.36 & 0.16 & 0.37 & 0.15 & 0.35 \\
\hline \multicolumn{7}{|l|}{ While studying } \\
\hline Worked occasionally ${ }^{* * *}$ & 0.51 & 0.50 & 0.54 & 0.50 & 0.51 & 0.50 \\
\hline Worked continuously.** & 0.08 & 0.27 & 0.09 & 0.28 & 0.07 & 0.26 \\
\hline Never worked*** & 0.41 & 0.49 & 0.38 & 0.48 & 0.43 & 0.49 \\
\hline Family network*** & 0.68 & 0.46 & 0.60 & 0.49 & 0.72 & 0.45 \\
\hline \multicolumn{7}{|l|}{ Sector of work } \\
\hline Chemical sector** & 0.07 & 0.25 & 0.06 & 0.24 & 0.07 & 0.25 \\
\hline Machinery*** & 0.04 & 0.19 & 0.06 & 0.24 & 0.03 & 0.16 \\
\hline Constructions ${ }^{* * *}$ & 0.07 & 0.26 & 0.08 & 0.28 & 0.07 & 0.25 \\
\hline Other industrial sectors*** & 0.18 & 0.38 & 0.19 & 0.39 & 0.17 & 0.37 \\
\hline Trade and hotels ${ }^{* * *}$ & 0.07 & 0.26 & 0.11 & 0.31 & 0.05 & 0.23 \\
\hline Transportation, tours, postal services and telecommunications ${ }^{* * *}$ & 0.10 & 0.30 & 0.07 & 0.26 & 0.11 & 0.32 \\
\hline Credit and insurance ${ }^{* * *}$ & 0.10 & 0.30 & 0.08 & 0.27 & 0.11 & 0.31 \\
\hline Other professional and consulting activities*** & 0.09 & 0.29 & 0.08 & 0.27 & 0.09 & 0.29 \\
\hline Informatics and similar activities & 0.06 & 0.23 & 0.05 & 0.23 & 0.06 & 0.23 \\
\hline Education and training & 0.05 & 0.22 & 0.05 & 0.23 & 0.05 & 0.22 \\
\hline Health and social assistance ${ }^{* * *}$ & 0.07 & 0.26 & 0.06 & 0.24 & 0.08 & 0.27 \\
\hline
\end{tabular}


Table 1 (continued)

\begin{tabular}{|c|c|c|c|c|c|c|}
\hline & \multicolumn{2}{|c|}{ All sample } & \multicolumn{2}{|c|}{ Densest provinces } & \multicolumn{2}{|c|}{ Rest of the country } \\
\hline & Mean & St.dev & Mean & St.dev & Mean & St.dev \\
\hline Public administration*** & 0.03 & 0.16 & 0.02 & 0.13 & 0.03 & 0.17 \\
\hline Other social services & 0.08 & 0.27 & 0.08 & 0.27 & 0.08 & 0.27 \\
\hline Experience in months ${ }^{* * *}$ & 23.61 & 11.97 & 23.95 & 11.95 & 23.61 & 11.97 \\
\hline $1998^{* * *}$ & 0.27 & 0.44 & 0.25 & 0.43 & 0.28 & 0.45 \\
\hline $2001^{* * *}$ & 0.36 & 0.48 & 0.36 & 0.48 & 0.33 & 0.47 \\
\hline 2004 & 0.37 & 0.48 & 0.37 & 0.48 & 0.37 & 0.48 \\
\hline \multicolumn{7}{|l|}{ Characteristics of the province of work $\ddagger$} \\
\hline Population density ${ }^{* * *}$ & 2.43 & 3.30 & 8.97 & 7.24 & 1.65 & 0.82 \\
\hline Unemployment rate & 9.20 & 7.42 & 7.05 & 6.79 & 9.45 & 7.49 \\
\hline Value added (in 1994) & 20.69 & 8.20 & 23.72 & 5.68 & 20.33 & 8.40 \\
\hline Share of self-employed workers in the individual's sector*** & 0.15 & 0.02 & 0.18 & 0.02 & 0.15 & 0.02 \\
\hline House prices per square metre ${ }^{* * *}$ & 3896.44 & 1259.61 & 4858.33 & 1883.30 & 3781.43 & 1124.02 \\
\hline Share of local bank counters in total counters* & 0.39 & 0.19 & 0.29 & 0.15 & 0.40 & 0.19 \\
\hline Tradition of political autonomy & 0.49 & 0.50 & 0.55 & 0.52 & 0.48 & 0.50 \\
\hline Collective action propensity & -0.01 & 1.00 & 0.40 & 0.91 & -0.06 & 1.00 \\
\hline Blood donation & 28.39 & 21.33 & 29.57 & 21.63 & 28.25 & 21.41 \\
\hline Number of associations per 100,000 inhabitants (in 1985) & 30.47 & 20.86 & 31.96 & 15.32 & 30.29 & 21.49 \\
\hline Welfare index & 105.05 & 30.76 & 105.99 & 27.68 & 104.93 & 31.25 \\
\hline Voter turnover at $1946-1989$ referenda* & 80.14 & 8.27 & 84.30 & 7.77 & 79.64 & 8.23 \\
\hline Share of municipalities with city sewer system & 98.30 & 7.05 & 96.43 & 9.89 & 98.52 & 6.67 \\
\hline Employee-self-employed earning ratio (in log) & 1.01 & 0.02 & 1.00 & 0.01 & 1.01 & 0.02 \\
\hline Average wages of employees (in log) & 1.87 & 0.06 & 1.88 & 0.05 & 1.87 & 0.06 \\
\hline No. observations & \multicolumn{2}{|c|}{33,740} & \multicolumn{2}{|c|}{14,806} & \multicolumn{2}{|c|}{18,934} \\
\hline
\end{tabular}

Notes: Computed on employed individuals. Variables denoted with ${ }^{*}(* *)[* * *]$ indicate that the difference between the most densely populated provinces and the rest of the country is statistical significant at the 10 (5) [1]\% level. The provinces in top 10th percentile of the population density distribution (i.e., having more than 383,437 inhabitants per square kilometre), defined as the densest provinces, are: Naples, Milan, Trieste, Rome, Varese, Prato, Rimini, Genoa, Como, Padova and Lecco. $\dagger$ Computed on 4,533 individuals (i.e, the entrepreneurs). $\ddagger$ Provincial characteristics have been computed on the universe of provinces. $\star$ Per 100 inhabitants per square kilometre. See the Appendix for a detailed description of the provincial variables.

manage different people), efficient, and well organized. According to the Jack-of-All-Trades entrepreneur hypothesis (see Lazear, 2005) entrepreneurship is favoured by a balanced mix of skills across various fields of expertise, which is innate rather than acquired at school (Silva, 2007). Conversely, being able to organize one's self so as to graduate on time is a quality better reflecting the capabilities required for working as an entrepreneur than school grade, especially in the light of the fact that in Italy most people graduate with a certain delay (just $15 \%$ of the sampled individuals graduated on time; Table 1$){ }^{4}$

\subsection{The potential endogeneity problem}

Our estimates of urbanization are unbiased and consistent only under the hypothesis that we have not omitted any variable correlated to provinces' population density. Conversely, if individuals' composition across markets of different density varied along unobservable dimensions that affected the probability of being an entrepreneur, previous section's urbanization estimates would be biased and inconsistent. In particular, the negative urbanization effect could be due (entirely or in part) to a higher endowment of people less capable of becoming entrepreneurs in the most densely populated markets for unobservable reasons, although this would be in contrast to the literature (e.g., Nocke, 2006).

In this section we deal with the potential endogeneity problem by instrumenting urbanization with pre-World War II population density (in 1921), similarly to Ciccone and Hall (1996), Rice et al. (2006), Combes et al. (2008) and Guiso and Schivardi (forthcoming). Indeed,

\footnotetext{
${ }^{4}$ We are aware of the fact that the graduating-on-time effect might be affected by reverse causation (if the students wanting to be entrepreneurs finished university in a shorter time than the others), as suggested by an anonymous referee. However, to the extent that occupational choices are made after graduation or towards the end of college, the graduating-on-time variable would not suffer from this problem. Nevertheless, our urbanization results are robust to excluding this variable from the regressions.
}

while the population density distribution has been stable over time, its 1921 pattern should have no direct effect on current entrepreneurship chances besides the indirect impact through current population density.

Results are reported in Table 3. Strikingly, we obtain the same outcome as before across all the columns (replicating Table 2's specifications), showing no evidence of a systematic bias in the OLS regressions, thus supporting our causal interpretation of urbanization. ${ }^{5}$ In particular, doubling the province's population density reduces the probability of being an entrepreneur by $2-3$ percentage points (at the $1 \%$ statistical significance level).

Table 3 also reports the first-stage results of the instrument used, the pseudo $R$-squared statistic and a measure of instrument relevance. As expected, population density in 1921 is positive and significant (at the $1 \%$ level) across all the columns. The partial $R$-squared statistic, measuring the correlation between urbanization and the instruments after partialling out the effect of the other exogenous variables, has very high values (above 0.92). The first-stage F-statistic of the excluded instruments, a diagnostic tool to evaluate the seriousness of the finite-sample bias and instrument weakness (Bound et al., 1995), always rejects the null hypothesis that our instrument is equal to zero. Since the 2SLS and the probit estimation coefficients are very similar in size and the Hausman test can never reject the null hypothesis of no difference between them (results not reported but available upon request), in what follows we will refer to Table 2's results as to our main findings.

\section{Potential explanations of the negative urbanization effect}

We have showed that the probability that a college graduate becomes an entrepreneur three years after graduation decreases with

\footnotetext{
${ }^{5}$ Note that other papers using Italian data find that OLS and IV urbanization estimates are highly similar (e.g., Guiso and Schivardi (forthcoming) and Di Addario and Patacchini, 2008).
} 
Table 2

Urbanization effect on the probability of being entrepreneur (marginal effects).

\begin{tabular}{|c|c|c|c|c|c|}
\hline & 2.1 & 2.2 & 2.3 & 2.4 & 2.5 \\
\hline Population density (in log) & $\begin{array}{c}-0.0300^{* * *} \\
(0.0041)\end{array}$ & $\begin{array}{c}-0.0261^{* * *} \\
(0.0034)\end{array}$ & $\begin{array}{c}-0.0273^{* * *} \\
(0.0035)\end{array}$ & $\begin{array}{c}-0.0213^{* * *} \\
(0.0035)\end{array}$ & $\begin{array}{c}-0.0216^{* * *} \\
(0.0032)\end{array}$ \\
\hline Female & $\begin{array}{c}-0.0661^{* * *} \\
(0.0064)\end{array}$ & $\begin{array}{c}-0.0611^{* * *} \\
(0.0034)\end{array}$ & $\begin{array}{c}-0.0591^{* * *} \\
(0.0035)\end{array}$ & $\begin{array}{c}-0.0578^{* * *} \\
(0.0033)\end{array}$ & $\begin{array}{r}-0.0577^{* * *} \\
(0.0032)\end{array}$ \\
\hline Married & $\begin{array}{c}0.003 \\
(0.0057)\end{array}$ & $\begin{array}{l}0.0122^{* *} \\
(0.0050)\end{array}$ & $\begin{array}{l}0.0123^{* *} \\
(0.0051)\end{array}$ & $\begin{array}{l}0.0127^{* *} \\
(0.0050)\end{array}$ & $\begin{array}{c}0.0148^{* * *} \\
(0.0045)\end{array}$ \\
\hline Age & $\begin{array}{c}-0.0699^{* * *} \\
(0.0212)\end{array}$ & $\begin{array}{c}-0.0466^{* *} \\
(0.0198)\end{array}$ & $\begin{array}{c}-0.0389^{* *} \\
(0.0197)\end{array}$ & $\begin{array}{c}-0.0356^{*} \\
(0.0189)\end{array}$ & $\begin{array}{c}-0.0297^{*} \\
(0.0152)\end{array}$ \\
\hline Age squared & $\begin{array}{c}0.0013^{* * *} \\
(0.0003)\end{array}$ & $\begin{array}{l}0.0008^{* *} \\
(0.0003)\end{array}$ & $\begin{array}{l}0.0007^{* *} \\
(0.0003)\end{array}$ & $\begin{array}{l}0.0007^{* *} \\
(0.0003)\end{array}$ & $\begin{array}{l}0.0005^{* *} \\
(0.0003)\end{array}$ \\
\hline Ph.D. degree & $\begin{array}{l}-0.0054 \\
(0.0406)\end{array}$ & $\begin{array}{l}-0.0385 \\
(0.0307)\end{array}$ & $\begin{array}{l}-0.0354 \\
(0.0317)\end{array}$ & $\begin{array}{l}-0.0383 \\
(0.0299)\end{array}$ & $\begin{array}{l}-0.0125 \\
(0.0302)\end{array}$ \\
\hline Number of siblings & $\begin{array}{c}0.0015 \\
(0.0023)\end{array}$ & $\begin{array}{l}-0.0001 \\
(0.0023)\end{array}$ & $\begin{array}{l}-0.0009 \\
(0.0023)\end{array}$ & $\begin{array}{c}0.0033 \\
(0.0022)\end{array}$ & $\begin{array}{c}0.0018 \\
(0.0022)\end{array}$ \\
\hline \multicolumn{6}{|c|}{ High school characteristics: lyceum omitted } \\
\hline Teachers' training school & & $\begin{array}{c}-0.0399^{* * * *} \\
(0.0103)\end{array}$ & $\begin{array}{c}-0.0327^{* * *} \\
(0.0110)\end{array}$ & $\begin{array}{c}-0.0334^{* * *} \\
(0.0109)\end{array}$ & $\begin{array}{c}-0.0168^{*} \\
(0.0101)\end{array}$ \\
\hline School for surveyors & & $\begin{array}{c}-0.007 \\
(0.0049)\end{array}$ & $\begin{array}{c}0.0038 \\
(0.0048)\end{array}$ & $\begin{array}{c}0.0018 \\
(0.0049)\end{array}$ & $\begin{array}{l}-0.0031 \\
(0.0044)\end{array}$ \\
\hline Vocational school & & $\begin{array}{c}0.0114 \\
(0.0104)\end{array}$ & $\begin{array}{l}0.0240^{* *} \\
(0.0114)\end{array}$ & $\begin{array}{c}0.0197^{*} \\
(0.0115)\end{array}$ & $\begin{array}{l}0.0209^{* *} \\
(0.0105)\end{array}$ \\
\hline \multicolumn{6}{|c|}{ Father's education: primary education omitted } \\
\hline Middle school & & & $\begin{array}{c}0.0069 \\
(0.0069)\end{array}$ & $\begin{array}{c}0.0068 \\
(0.0067)\end{array}$ & $\begin{array}{c}0.0108^{*} \\
(0.0064)\end{array}$ \\
\hline High school & & & $\begin{array}{c}0.0051 \\
(0.0077)\end{array}$ & $\begin{array}{c}0.0035 \\
(0.0076)\end{array}$ & $\begin{array}{c}0.0071 \\
(0.0069)\end{array}$ \\
\hline College degree & & & $\begin{array}{l}0.0242^{* *} \\
(0.0106)\end{array}$ & $\begin{array}{l}0.0205^{* *} \\
(0.0096)\end{array}$ & $\begin{array}{c}0.0143 \\
(0.0087)\end{array}$ \\
\hline \multicolumn{6}{|c|}{ Mother's education: primary education omitted } \\
\hline Middle school & & & $\begin{array}{c}0.0072 \\
(0.0058)\end{array}$ & $\begin{array}{c}0.0049 \\
(0.0057)\end{array}$ & $\begin{array}{c}0.0047 \\
(0.0054)\end{array}$ \\
\hline High school & & & $\begin{array}{l}0.0144^{* *} \\
(0.0066)\end{array}$ & $\begin{array}{l}0.0133^{* *} \\
(0.0066)\end{array}$ & $\begin{array}{l}0.0098^{*} \\
(0.0055)\end{array}$ \\
\hline College degree & & & $\begin{array}{c}0.0081 \\
(0.0086)\end{array}$ & $\begin{array}{c}0.0086 \\
(0.0085)\end{array}$ & $\begin{array}{c}0.0069 \\
(0.0082)\end{array}$ \\
\hline \multicolumn{6}{|l|}{ Parents' occupational status } \\
\hline Self-employed father & & & $\begin{array}{l}0.0934^{* * * *} \\
(0.0074)\end{array}$ & $\begin{array}{c}0.0860^{* * * *} \\
(0.0073)\end{array}$ & $\begin{array}{c}0.0559^{* * * *} \\
(0.0068)\end{array}$ \\
\hline Self-employed mother & & & $\begin{array}{l}0.0377^{* *} \\
(0.0188)\end{array}$ & $\begin{array}{c}0.0368^{*} \\
(0.0192)\end{array}$ & $\begin{array}{c}0.0194 \\
(0.0160)\end{array}$ \\
\hline \multicolumn{6}{|l|}{ Ability proxies } \\
\hline Final grade at college & & & & $\begin{array}{c}0.0095 \\
(0.0075)\end{array}$ & $\begin{array}{l}-0.0007 \\
(0.0062)\end{array}$ \\
\hline Final grade at college squared & & & & $\begin{array}{c}-0.0001 \\
0.0000\end{array}$ & $\begin{array}{l}0.0000 \\
0.0000\end{array}$ \\
\hline Laude & & & & $\begin{array}{c}0.0051 \\
(0.0056)\end{array}$ & $\begin{array}{c}0.0027 \\
(0.0050)\end{array}$ \\
\hline Graduated on time & & & & $\begin{array}{l}0.0130^{* *} \\
(0.0051)\end{array}$ & $\begin{array}{l}0.0115^{* *} \\
(0.0045)\end{array}$ \\
\hline \multicolumn{6}{|c|}{ While studying: never worked omitted } \\
\hline Worked occasionally & & & & $\begin{array}{c}-0.0184^{* * *} \\
(0.0039)\end{array}$ & $\begin{array}{r}-0.0169^{* * *} \\
(0.0035)\end{array}$ \\
\hline Worked continuously & & & & $\begin{array}{l}-0.0067 \\
(0.0065)\end{array}$ & $\begin{array}{c}-0.0098^{*} \\
(0.0056)\end{array}$ \\
\hline Family network & & & & $\begin{array}{c}0.0766^{* * * *} \\
(0.0067)\end{array}$ & $\begin{array}{l}0.0565^{* * *} \\
(0.0041)\end{array}$ \\
\hline Experience in months & & & & & $\begin{array}{c}0.0017^{* * * *} \\
(0.0002)\end{array}$ \\
\hline Survey year & Yes & Yes & Yes & Yes & Yes \\
\hline Region dummies & Yes & Yes & Yes & Yes & Yes \\
\hline Type of degree & Yes & Yes & Yes & Yes & Yes \\
\hline Sector of work & No & No & No & No & Yes \\
\hline No. observations & 33,740 & 33,740 & 33,740 & 33,740 & 33,740 \\
\hline
\end{tabular}

White-robust standard errors adjusted for clustering at the provincial level are reported in parentheses. The type of degree categories include: chemistry-pharmaceutical, biology and geology, medicine, science, engineering, architecture, agriculture, political and social science, law, humanities, foreign languages, teaching, and psychology (economics and statistics omitted). The sector categories include: distribution services, hotels and restaurants; transport, travel and communication services; financial services; professional services (legal and architectural services, consultancies, market research, public opinion polling services, real estate services, rental/leasing services, advertising and research and development); computer and related services; educational services; health related and social services; public administration; chemicals, drugs and pharmaceuticals; engineering industry, machinery and equipment; other industries; and construction (other public, social and personal services omitted). Omitted region: Piedmont. Symbols: The asterisk ${ }^{*}(* *)$ [***] indicates statistical significance at the 10 (5) [1]\% level. 
Table 3

Instrumental variables estimates of the urbanization effect on the probability of being entrepreneur.

\begin{tabular}{|c|c|c|c|c|c|}
\hline & 3.1 & 3.2 & 3.3 & 3.4 & 3.5 \\
\hline Population density (in log) & $\begin{array}{c}-0.0318^{* * *} \\
(0.0041)\end{array}$ & $\begin{array}{c}-0.0261^{* * * *} \\
(0.0036)\end{array}$ & $\begin{array}{c}-0.0272^{* * *} \\
(0.0036)\end{array}$ & $\begin{array}{c}-0.0209^{* * * *} \\
(0.0039)\end{array}$ & $\begin{array}{c}-0.0243^{* * *} \\
(0.0037)\end{array}$ \\
\hline \multicolumn{6}{|l|}{ Instruments } \\
\hline Population density in 1921 (in log) & $\begin{array}{l}1.1895^{* * *} \\
(0.0440)\end{array}$ & $\begin{array}{l}1.1882^{* * * *} \\
(0.0438)\end{array}$ & $\begin{array}{l}1.1880^{* * * *} \\
(0.0438)\end{array}$ & $\begin{array}{l}1.1867^{* * *} \\
(0.0437)\end{array}$ & $\begin{array}{c}1.18461^{* * * *} \\
(0.0436)\end{array}$ \\
\hline Partial R-squared of excluded instruments: & 0.8999 & 0.8994 & 0.8991 & 0.8979 & 0.8970 \\
\hline Test of excluded instruments ( $F$-test): & 731.26 & 735.79 & 735.48 & 735.55 & 738.2400 \\
\hline No. observations & 33,740 & 33,740 & 33,740 & 33,740 & 33,740 \\
\hline
\end{tabular}

White-robust standard errors adjusted for clustering at the provincial level are reported in parentheses. In columns (3.1)-(3.5) we control for the same covariates as in Table 2. The asterisk ${ }^{*}(* *)\left[{ }^{* * *}\right]$ indicates statistical significance at the $10(5)[1] \%$ level.

provinces' population density. This result holds after controlling for a wide variety of individual characteristics and regional fixed effects, and it is robust to correcting for the potential endogeneity of urbanization. The lack of endogeneity is not too surprising in the light of the fact that geographical labour mobility is particularly low in Italy, especially among the self-employed individuals (see the Introduction). In this section we test whether the negative impact of urbanization persists after controlling for some characteristics of the province of work that might be correlated with population density (see Table 1). To investigate this possibility, we add the province characteristics described below (see the Appendix for further details) to our benchmark specification (reported in column (2.5)). Since we assume that the provincial variables are exogenous, our approach is to be considered as purely descriptive. Results are shown in Table 4 .

First, we test whether the negative urbanization differential can be explained by the densest markets' more intense competition (see Combes et al., 2009), which might discourage particularly young people at the beginning of their career. Indeed, rivalry may lower firms' price-cost margins, requiring, thus, a level of efficiency that entrepreneurs might acquire only through experience. We measure competition with the share of the individual sector's self-employed workers in total self-employed workers (column (4.1)). As expected, the more intense is rivalry the less likely is that college graduates become entrepreneurs. Most importantly, controlling for competition reduces the size of the urbanization coefficient by almost a third (from -0.0216 in the benchmark specification, to -0.0151 ).

In the second specification $((4.2))$ we test whether young college graduates are particularly discouraged from starting their own activities in the most densely populated provinces because land is most expensive, raising firms' fixed set up costs. In case of credit market imperfections, the increased difficulties of financing the extra initial investment necessary to cover the higher fixed costs in the most densely populated markets might be particularly binding for young entrepreneurs. In the quality-of-life-framework (Roback, 1982) firms prefer locating in the most amenity-intensive markets as long as their utility from productive urban amenities (e.g., availability of infrastructures like airports, better quality services, specialized schools, etc.) exceeds the dis-utility from congestion. ${ }^{6}$ Congestion may discourage more the young than the experienced entrepreneurs, because in saturated local markets received prices might be lower than elsewhere (Henderson, 1994), increasing the difficulties of starting-up. We measure urban dis-amenities with house prices per square metre. Introducing house prices reduces the urbanization effect (with respect to our benchmark) by just $8 \%$ : doubling the

\footnotetext{
${ }^{6}$ However, if the amenities in the most densely populated markets were unproductive (e.g., higher number of cinemas and theatres, greater variety of shopping centres, wider offer of sport venues, etc.), entrepreneurs would unambiguously prefer locating in low-amenities places, where land prices are lower. In this case only employees would prefer living in the most densely populated provinces.
}

province's population density reduces the probability of being entrepreneur by 2.0 percentage points.

Third, we test whether young college graduates are encouraged to start their activities in the least densely populated markets because these are endowed with the amenities entrepreneurs most care for. For instance, entrepreneurs might prefer locating in the provinces with a stronger culture of entrepreneurship (Glaeser, 2007), a higher social capital or a larger presence of local banks. In Italy, the most entrepreneurial areas, richer of social capital and civic endowment, coincide to a large extent with the municipalities that in the Middle Ages become republics (as opposed to the Southern monarchical regions), which are, indeed, small- and medium-sized (Putnam, 1993). ${ }^{7}$ Thus, in column (4.3) we include five proxies of social capital à la Putnam (1993): number of associations per 100,000 inhabitants, tradition of political autonomy, propensity to collective action, average voter turnout at all Italian referenda held between 1946 and 1989, and blood donation (as in Guiso et al., 2004). We also add the share of provinces' municipalities with a city sewer system and an index of welfare (inversely related to provinces' population density), meant to capture the fact that entrepreneurs might prefer living in the least densely populated provinces because they offer a better quality of life. In this specification we also control for the share of local banks' counters in total banks' counters, which is highest in the least dense markets. Indeed, accessing external financing might be particularly difficult for young entrepreneurs (in spite of being at a stage of the life cycle when they need to rely more on it), because banks judge their activity very risky (see Blanchflower and Oswald, 1998). We expect this variable to have a positive direct effect on entrepreneurship, because local banks are thought of facilitating local entrepreneurs' start-up financing, as they generally both have local owners and are specialized in providing credit locally (Farabullini and Gobbi, 2000). Column (4.3) shows that the individuals living in the provinces with a higher share of local banks have a higher probability of becoming entrepreneurs, as expected. The only other significantly positive amenity variable is the propensity to collective action. Overall, urban amenities explain one fifth of the urbanization effect: doubling population density reduces the chances of entrepreneurship by 1.8 percentage points.

Fourth, we test whether young college graduates are discouraged from starting an activity of their own in the most densely populated markets because, on average, they have to pay a higher cost of labour. To test this hypothesis, we add the province's average employee wage, and we find that it is not significant; the urbanization effect is the same as in the benchmark specification (column (4.4)).

\footnotetext{
${ }^{7}$ As the author suggests, the current economic development of Italian provinces depends more on the civic endowment built in the Middle Ages than on their initia economic conditions, and causality runs from civics to economics rather than the
} reverse. 
Table 4

Urbanization effect on the probability of being entrepreneur: testing alternative hypotheses (marginal effects).

\begin{tabular}{|c|c|c|c|c|c|c|c|}
\hline & 4.1 & 4.2 & 4.3 & 4.4 & 4.5 & 4.6 & 4.7 \\
\hline Population density (in log) & $\begin{array}{c}-0.0151^{* * *} \\
(0.0028)\end{array}$ & $\begin{array}{c}-0.0197^{* * *} \\
(0.0035)\end{array}$ & $\begin{array}{c}-0.0176^{* * *} \\
(0.0029)\end{array}$ & $\begin{array}{c}-0.0215^{* * *} \\
(0.0032)\end{array}$ & $\begin{array}{c}-0.0216^{* * *} \\
(0.0032)\end{array}$ & $\begin{array}{c}-0.0187^{* * *} \\
(0.0037)\end{array}$ & $\begin{array}{c}-0.0094^{* *} \\
(0.0039)\end{array}$ \\
\hline Share of self-employed workers in the individual's sector & $\begin{array}{c}-0.2979 * * * \\
(0.0606)\end{array}$ & & & & & & $\begin{array}{c}-0.2909^{* * *} \\
(0.0601)\end{array}$ \\
\hline House price per square metre† & & $\begin{array}{l}-0.0023 \\
(0.0022)\end{array}$ & & & & & $\begin{array}{l}-0.0019 \\
(0.0022)\end{array}$ \\
\hline Share of local banks in total counters & & & $\begin{array}{l}0.0516^{* * *} \\
(0.0203)\end{array}$ & & & & $\begin{array}{l}0.0450^{* *} \\
(0.0189)\end{array}$ \\
\hline Tradition of political autonomy & & & $\begin{array}{c}0.0061 \\
(0.0059)\end{array}$ & & & & $\begin{array}{c}0.0043 \\
(0.0052)\end{array}$ \\
\hline Collective action propensity & & & $\begin{array}{c}0.0139^{* * *} \\
(0.0044)\end{array}$ & & & & $\begin{array}{c}0.0132^{* * *} \\
(0.0047)\end{array}$ \\
\hline Blood donation & & & $\begin{array}{c}0.0001 \\
(0.0002)\end{array}$ & & & & $\begin{array}{c}0.0000 \\
(0.0002)\end{array}$ \\
\hline No. of associations per 100,000 inhabitants (in 1985) & & & $\begin{array}{l}-0.0001 \\
(0.0001)\end{array}$ & & & & $\begin{array}{l}-0.0001 \\
(0.0001)\end{array}$ \\
\hline Welfare index & & & $\begin{array}{l}-0.0002 \\
(0.0001)\end{array}$ & & & & $\begin{array}{l}-0.0002 \\
(0.0001)\end{array}$ \\
\hline Voter turnover at 1946-1989 referenda & & & $\begin{array}{c}0.0012 \\
(0.0010)\end{array}$ & & & & $\begin{array}{c}0.0016 \\
(0.0010)\end{array}$ \\
\hline Share of municipalities with city sewer system & & & $\begin{array}{c}0.0002 \\
(0.0002)\end{array}$ & & & & $\begin{array}{c}0.0002 \\
(0.0003)\end{array}$ \\
\hline Average employees wages (in log) $\ddagger$ & & & & $\begin{array}{l}-0.0214 \\
(0.0384)\end{array}$ & & & $\begin{array}{l}-0.0093 \\
(0.0398)\end{array}$ \\
\hline Employees/self-employed earning ratio (in log) $\ddagger$ & & & & & $\begin{array}{c}-0.071 \\
(0.0800)\end{array}$ & & $\begin{array}{l}-0.0263 \\
(0.0825)\end{array}$ \\
\hline Unemployment rate & & & & & & $\begin{array}{l}-0.0011 \\
(0.0007)\end{array}$ & $\begin{array}{l}-0.0008 \\
(0.0008)\end{array}$ \\
\hline Value added (in 1994) & & & & & & $\begin{array}{l}-0.0004 \\
(0.0003)\end{array}$ & $\begin{array}{c}0.0001 \\
(0.0003)\end{array}$ \\
\hline No. observations & 33,740 & 33,740 & 33,740 & 33,737 & 33,737 & 33,737 & 33,737 \\
\hline
\end{tabular}

White-robust standard errors adjusted for clustering at the provincial level are reported in parentheses. $\dagger$ Coefficient multiplied by $100 . \pm$ Averages computed by province and year. In all the columns we control for the same covariates as in specification (2.5) (Table 2$)$. For a detailed explanation of the provincial variables, see the Appendix. The asterisk ${ }^{*}\left({ }^{* *}\right)\left[{ }^{* * *}\right]$ indicates statistical significance at the 10 (5) [1]\% level.

Fifth, we test whether the provinces with a higher population density discourage entrepreneurship because of their greater offer of a wider variety of outside options (e.g., working as employees in the public sector, in large firms, etc.). Indeed, the densest markets are generally endowed with a larger public sector than the least densely populated provinces, and thus have a tendency to offer above all salaried-job opportunities, not encouraging young college graduates to start entrepreneurial activities. ${ }^{8}$ Conversely, the least densely populated markets, where the offer of jobs in the public sector is more limited, might provide a higher incentive for entrepreneurship out of necessity. Thus, in this specification we control for the log of the ratio between the province's average employee wages and the province's average earnings from entrepreneurship, to test whether in the densest market the difference between earnings from entrepreneurship and wages is or is not sufficient to cover the risk of starting a business activity. However, this variable is non-significant and, not surprisingly, the urbanization effect is the same as in column (2.5) (specification (4.5)).

Sixth, we test whether the negative urbanization differential persists after controlling for two proxies of local economic development: the province's unemployment rate and value added per capita in 1994, similarly to Michelacci and Silva (2007). ${ }^{9}$ Indeed,

\footnotetext{
${ }^{8}$ In this line, Torrini (2005) shows that in OECD countries the larger the public sector size, the lower the self-employment rates. According to the author, the public sector is likely to crowd out self-employment especially in the general administration (where entrepreneurship does not exist) or in education and health (where the government is typically more present).

9 Similarly to the authors, we use value added in a year preceding the labour market entrance of the first wave of the sampled individuals (in 1995), because this enables us to capture the effect of an exogenous variation in local economic development on the probability of being an entrepreneur.
}

people may decide to start an activity of their own out of necessity not only because of a limited variety of job types offered, but also because of low employment chances (especially in a context of little labour mobility). Thus, if the least densely populated provinces were also the poorest, our results could be driven by sample composition rather than by urbanization: the greater likelihood of becoming entrepreneurs in the least densely populated markets could be due to a higher share of individuals lacking alternative opportunities. However, specification (4.6) shows that neither unemployment rates nor value added per capita is significant, implying that in Italy individuals do not generally choose entrepreneurship out of necessity, in line with Michelacci and Silva (2007). Thus, including unemployment rate and value added per capita leaves the urbanization coefficient almost unchanged with respect to our benchmark specification $(-0.0187)$.

Finally, in the last specification $((4.7))$ we include all the provincial variables reported in columns (4.1)-(4.6). Results indicate that young entrepreneurs are discouraged from starting their business in the most competitive areas, while they are encouraged by social capital endowment in the least densely populated markets (in particular, by the presence of local banks and people's propensity to collective action). When considered jointly, these factors explain $55 \%$ of the urbanization effect in the benchmark specification.

\section{Returns to entrepreneurship}

We have shown that the most densely populated is the market, the more young college graduates are discouraged from becoming entrepreneurs. In this section we test whether this phenomenon can be explained by the existence of monetary disincentives to 
Table 5

Urbanization effect on log monthly earnings from entrepreneurship.

\begin{tabular}{|c|c|c|c|c|c|}
\hline & 5.1 & 5.2 & 5.3 & 5.4 & 5.6 \\
\hline \multicolumn{6}{|l|}{ Panel A: OLS } \\
\hline Population density (in log) & $\begin{array}{l}0.0230^{* *} \\
(0.0103)\end{array}$ & $\begin{array}{c}0.0295^{* * *} \\
(0.0105)\end{array}$ & $\begin{array}{c}0.0275^{* * * *} \\
(0.0104)\end{array}$ & $\begin{array}{c}0.0201^{*} \\
(0.0104)\end{array}$ & $\begin{array}{c}0.0181^{*} \\
(0.0102)\end{array}$ \\
\hline \multicolumn{6}{|l|}{ Panel B: IV } \\
\hline Density (in log) & $\begin{array}{l}0.0231^{* *} \\
(0.0101)\end{array}$ & $\begin{array}{c}0.0280^{* * *} \\
(0.0098)\end{array}$ & $\begin{array}{c}0.0260^{* * *} \\
(0.0097)\end{array}$ & $\begin{array}{c}0.0187^{*} \\
(0.0097)\end{array}$ & $\begin{array}{c}0.0168^{*} \\
(0.0096)\end{array}$ \\
\hline \multicolumn{6}{|l|}{ First stage - instruments } \\
\hline Population density in 1921 (in log) & $\begin{array}{l}1.1796^{* * *} \\
(0.0411)\end{array}$ & $\begin{array}{l}1.1780^{* * *} \\
(0.0408)\end{array}$ & $\begin{array}{l}1.1775^{* * *} \\
(0.0407)\end{array}$ & $\begin{array}{l}1.1762^{* * *} \\
(0.0407)\end{array}$ & $\begin{array}{c}1.1764^{* * *} \\
(0.0406)\end{array}$ \\
\hline Partial $R$-squared of excluded instruments: & 0.8976 & 0.8967 & 0.8964 & 0.8954 & 0.8953 \\
\hline Test of excluded instruments (F-test): & 822.31 & 833.58 & 834.66 & 835.64 & 841.23 \\
\hline No. observations & 4533 & 4533 & 4533 & 4533 & 4533 \\
\hline
\end{tabular}

White-robust standard errors adjusted for clustering at the provincial level are reported in parentheses. In columns (5.1)-(5.5) we control for the same covariates as in Table 2. The asterisk $\left.{ }^{*}{ }^{* *}\right)^{\left.{ }^{* * *}\right]}$ indicates statistical significance at the $10(5)[1] \%$ level.

entrepreneurship growing with population density. Indeed, other studies on Italian employees find that college graduates are less able than the least educated workers to reap-off the benefits from agglomeration externalities (whether urban or industrial). For instance, Di Addario and Patacchini (2008) obtain that employees with at least a university degree earn $0.4-0.5 \%$ less each 100 inhabitant increase in the population of the local labour market of residence, in spite overall average wages raise by $0.1 \%$. Similarly, according to de Blasio and Di Addario (2005) college graduates' earnings from salaried work are $9-14 \%$ lower in industrial districts (i.e., the local labour markets with a strong agglomeration of smalland medium-sized manufacturing firms) than elsewhere in the country. Conversely, the employees with elementary education or less earn a premium over their counterparts outside industrial districts.

In fact, the descriptive statistics reported in Table 1 would not support the hypothesis of negative correlation between earnings from entrepreneurship and province's population density, because on average entrepreneurs earn about $10.0 \%$ more in the most densely populated provinces than elsewhere (Table 1). Nevertheless, we examine whether this is still the case after controlling for individuals' characteristics. In particular, we estimate a standard Mincerian earning function (Mincer, 1958) by regressing the logarithm of entrepreneurs' monthly earnings on the individual characteristics reported in Table 2 .

Results, shown in Table 5 (Panel A), indicate that, after controlling for individual characteristics, income from entrepreneurship increases with population density, in line with the predictions of the literature. In particular, the elasticity of young educated entrepreneurs' monthly earnings with respect to the province of work's population density is $0.02-0.03$. However, OLS estimates would be biased and inconsistent if there were omitted variables affecting both urbanization and entrepreneurs' earnings (see Section 2). Thus, we re-estimate the earning equation by 2 SLS, instrumenting urbanization with the $\log$ of province population density in 1921. Results, shown in Table 5 (Panel B), confirm OLS findings.

The first-stage results, reported at the bottom of Table 5 , indicate that the log of population density in 1921 is always positive and significant at the $1 \%$ level across all the columns. The partial $R$-squared statistic is 0.90 , and the F-statistic of the excluded instruments always rejects the null hypothesis that our instrument is equal to zero. Finally, the Hausman test fails to reject the null hypothesis of no difference between the 2SLS and the OLS coefficients (results available upon request).
Thus, our results indicate that contrary to employees, entrepreneurs do benefit from urbanization externalities in monetary terms, at least to the extent that they succeed in opening an activity in the most densely populated markets.

\section{Conclusions}

In this paper we analyse empirically the effects of urbanization economies on the probability that Italian young college graduates become entrepreneurs. We find that doubling the province of work's population density lowers the probability of being an entrepreneur three years after graduation by $2-3$ percentage points. This result holds after controlling for regional fixed effects and is robust to instrumenting urbanization with the log of provinces' population density in 1921. Controlling for provinces' competition, urban amenities and dis-amenities, average cost of labour, earning differentials between employees and self-employed workers, and local economic development eliminates more than half of the negative urbanization penalty.

We then test whether our results could be explained by the presence of negative differentials in returns to entrepreneurship between the most and the least densely populated markets. In fact, we find that urbanization raises entrepreneurs' income: the elasticity of their monthly earnings with respect to population density is 0.02 0.03 . Thus, young entrepreneurs are able to reap-off the benefits from urbanization externalities, provided that they succeed in entering the most densely populated markets.

Our results are consistent with the entry cost theory: the locations with a higher share of entrepreneurs (i.e., the least densely populated ones) also exhibit lower individual earnings, and, thus, productivity. In contrast, Guiso and Schivardi (forthcoming) obtain a positive correlation between the incidence of entrepreneurs (of any age and education level) and TFP, using firm data at the Italian local labour market level. While our finding is certainly valid for the young and highly educated entrepreneurs, it would be interesting to establish whether wider ranged individual data would also confirm our result for the most experienced and the least educated entrepreneurs, or whether urbanization externalities differ according to education and/ or age. Moreover, while we have studied the effect of market density on the probability of being an entrepreneur, independently on whether individuals work in the province of birth, Michelacci and Silva (2007) show that entrepreneurs generally start their activity in the region of birth, independently of its population density. Future research could combine the two approaches to analyse whether the 
effect of population density on entrepreneurial choices depends on whether the individual works or not in the province of birth.

Finally, our results are policy-relevant. In 1995, for instance, the Italian Parliament passed a bill (L. 95/95) providing subsidies to the young entrepreneurs (below 35 years old) residing in the least developed regions of Italy (i.e., the South), in the rural areas or in zones in industrial decline (the European Commission's objective 1, 2 and $5 \mathrm{~b}){ }^{10}$ This paper shows that young college graduates are discouraged from starting their activity in the most densely populated provinces, in spite of the fact that they would gain a monetary premium there. It would thus be advisable to encourage the location of start-up firms in the densest rather than in the least densely populated markets. This would enable young entrepreneurs, who presumably face greater difficulties than more experienced entrepreneurs, to benefit from urbanization externalities. The importance of graduates' entrepreneurship should not be undervalued, because the youngest and most highly educated entrepreneurs might be more likely to introduce innovations than the oldest and least educated businessmen.

\section{Acknowledgments}

We are grateful to Giorgio Brunello, Arnaud Chevalier, Maria De Paola, Francesco Ferrante, Andrea Lamorgese, Francesca Lotti, Claudio Lucifora and an anonymous referee for useful comments. We thank Fabrizio Ferrari for his precious assistance, and L. Leva and S. Mocetti for providing us with the data on local banks and number of college graduates by province, respectively. Finally, we thank the participants to: the 50th Annual Meeting of the Societa' Italiana degli Economisti (22nd-24th October, Rome), the 2009 EALE Annual Conference (1012th September 2009, Tallin), and a Bank of Italy's seminar (17th December 2008, Rome). The views expressed in this paper are those of the authors and do not involve the responsibility of the Bank.

\section{Appendix A. Description of the provincial level variables}

Share of self-employed workers in the individual's sector in province's total self-employed workers. Source: ISTAT.

House prices per square metre (in 2004). Source: Consulente Immobiliare. The prices, provided by real estate agents, are those actually paid in transactions. We average the prices collected in the town centres, suburbs and in-between areas to take into account the house location. We also take into account the age of the building by averaging the prices of the recently build and the new houses.

Share of local bank counters in the province's total bank counters (in 2001). Source: the Bank of Italy. Local banks are the banks whose average investment funds amount to less than 9 billion euros.

Tradition of political autonomy. Source: Isl-University of Parma. This is a dummy variable equal to one if the province has a longstanding tradition of political autonomy (zero if the province belonged to the Vatican State or was a monarchy before Italy's foundation).

Propensity to collective action. Source: Arrighetti et al. (2001). This variable has been computed with a principal-component analysis on the basis of the following variables: the share of the craftsmen joining artisan associations in the number of artisan firms put on the register

\footnotetext{
10 Of course, young entrepreneurs could still apply for subsidies provided by other laws (e.g., L. 215/92, L. 236/93, L. 608/95, L. 608/96, L. 135/97 and L. 448/98) tailored for specific groups (i.e., women, small firms, etc.). The Law 95/95, specifically designed for young entrepreneurs, was previously financed in 1986 (L. 44/86), but was then circumscribed only to the South (though in 1994 it was extended to some of the least developed areas in the North). This bill provides both monetary and non-monetary incentives to locate in the most disadvantaged areas (i.e., subsidies or tax breaks, as well as technical assistance, tutoring and tailored training courses). Note that in order to test the effect of this law we would need data at the municipality level, while we only have them at the provincial level.
}

in 1970; the ratio between the number of votes in the 1970 elections for the Artisan Provincial Board and the number of artisans put on the register in 1970; the share of farms selling products to agricultural cooperatives in the number of farms in 1970; the ratio between the people joining buying associations and the number of trade licenses in 1965; a dummy variable equal to one if the province has at least one joint-surety association on bank loans joining Artigianfidi that was founded before 1975 (and zero otherwise).

Average voter turnout at all Italian referenda held in the period 19461989. Source: Guiso et al. (2004) elaboration on data from the Italian Ministry of Interior. The referenda held in the period considered were on the following subjects: choice between Monarchy and Republic (1946); divorce (1974); public financing to political parties (1978); anti-terrorism legislation and abortion (1981); cost of living index (1985); nuclear energy and hunting regulation (1987).

Number of blood sacks donated in the province per 1 million AVIS inhabitants (in 1995). Source: AVIS (Italian Voluntary Association for Blood). Each bag contains 16 oz. of blood. In four provinces (Genova, Caserta, Avellino and Caltanissetta) the value is set to zero because they do not host AVIS and presumably have very low blood donations.

Average number of associations per 100,000 inhabitants (in 1985). Source: Isl-University of Parma. This variable has been computed by subtracting the sporting and interest agencies' associations from the total. The municipal tourist boards associations are, instead, included.

Share of provinces' municipalities with a city sewer system. Source: ISTAT.

Welfare index. Source: Il Sole 24 Ore. The index, named Gross Domestic Welfare, is a combination of 8 variables at the provincial level: value added per inhabitant at current prices, life expectation at birth, enrolment rate at college, per capita expenditure for entertainment, participation to European elections in 2009, tons of CO2 in real value added, number of thefts, burglaries, and murders per 100,000 inhabitants, number of voluntary work associations per 1000 inhabitants.

Average wages for employees. Source: ISTAT. This variable, obtained from the SECCG, is the average of college graduate earnings ( 3 years after graduation).

Employee-Self-employed earning ratio. Source: ISTAT. This variable, obtained from the SECCG, is the ratio of average wages for employees and average earnings from entrepreneurship.

Unemployment rate. Source: ISTAT.

Value added in 1994. Source: ISTAT.

Population size in 1921. Source: ISTAT.

\section{References}

Alesina, Alberto, Algan, Yann, Cahuc, Pierre, Giuliano, Paola, 2010. Family Values and the Regulation of Labor. Working Paper No. 4747. IZA.

Arrighetti, A., Lasagni, A., Serravalli, G., 2001. Capitale sociale, associazionismo economico e istituzioni: indicatori statistici di sintesi. Working Paper No. 4/2001. Universita' di Parma, Serie: Economia e Politica economica.

Baldwin, Richard E., Okubo, Toshihiro, 2006. Heterogeneous firms, agglomeration and economic geography: spatial selection and sorting. Journal of Economic Geography $6,323-346$

Behrens, Kristian, Robert-Nicoud, Frederic, 2008. Survival of the fittest in cities: agglomeration, selection, and polarization. Discussion Paper No. 7018. CEPR.

Blanchflower, David G., 2000. Self-employment in OECD Countries. Labour Economics 7, 471-505.

Blanchflower, David G., Oswald, Andrew J., 1998. What makes an entrepreneur? Labour Economics 7, 471-505.

Bound, J., Jaeger, D., Baker, R., 1995. Problems with instrumental variables estimation when the correlation between the instruments and the endogenous explanatory variables is weak. Journal of American Statistical Association 90, 443-450.

Brunello, Giorgio, Cappellari, Lorenzo, 2008. The labour market effects of alma mater: evidence from Italy. Economics of Education Review 27, 564-574.

Calvo, G., Wellisz, S., 1980. Technology, entrepreneurs and firm size. Quarterly Journal of Economics 95, 663-678.

Card, David, 2001. Estimating the return to schooling: progress on some persistent econometric problems. Econometrica 69, 1127-1160.

Ciccone, Antonio, 2002. Agglomeration effects in Europe. European Economic Review $46,213-227$ 
Ciccone, Antonio, Hall, Robert E. 1996. Productivity and the density of economic activity. American Economic Review 78, 89-107.

Cingano, Federico, Schivardi, Fabiano, 2004. Identifying the source of local productivity growth. Journal of the European Economic Association 2, 720-742.

Combes, Pierre-Philippe, Duranton, Gilles, Gobillon, Laurent, Roux, Sébastien, 2008. Estimating Agglomeration Economies with History, Geology, and Worker Effects. mimeo.

Combes, Pierre-Philippe, Duranton, Gilles, Gobillon, Laurent, Puga, Diego, Roux Sébastien, 2009. The Productivity Advantages of Large Cities: Distinguishing Agglomeration from Firm Selection. mimeo.

de Blasio, Guido, Di Addario, Sabrina, 2005. Do workers benefit from industrial agglomeration? Journal of Regional Science 45, 797-827.

Di Addario, Sabrina, Patacchini, Eleonora, 2008. Wages and the city. Evidence from Italy. Labour Economics 15, 1040-1061.

Farabullini, Fabio, Gobbi, Giorgio, 2000. Le banche nei sistemi locali di produzione. In: Signorini, L.F. (Ed.), Lo sviluppo locale. Meridiana, Roma.

Glaeser, Edward L., 2007. Entrepreneurship and the city. Discussion Paper No. 2140. HIER.

Guiso, Luigi, Schivardi, Fabiano, 2007. Spillovers in industrial districts. The Economic Journal 117, 68-93.

Guiso, Luigi, Schivardi, Fabiano, forthcoming. What Determines Entrepreneurial Clusters? Journal of the European Economic Association.

Guiso, Luigi, Sapienza, Paola, Zingales, Luigi, 2004. The role of social capital in financial development. American Economic Review 94, 526-556.

Helsley, Robert W., Strange, William C., 1990. Matching and agglomeration economies in a system of cities. Regional Science and Urban Economics 20, 189-212.

Henderson, I. Vernon, 1983. Industrial bases and city sizes. The American Economic Review 73, 164-168.

Henderson, I. Vernon, 1994. Where does an industry locate? Journal of Urban Economics 35, 83-104

ISTAT, 2003. Parentela e reti di solidarieta'. Indagine multiscopo sulle famiglie. Istat, Rome.

Kim, Sunwoong, 1990. Labor heterogeneity, wage bargaining, and agglomeration economies. Journal of Urban Economics 28, 160-177.

LaFountain, Courtney, 2005. Where do firms locate? Testing competing models of agglomeration. Journal of Urban Economics 58, 338-366.

Lazear, Edward P., 2005. Entrepreneurship. Journal of Labor Economics 23, 649-680.

Le, A., 1999. Empirical studies of self-employment. Journal of Economic Surveys 13, 381-416.
Makovec, Mattia, 2006. Does it Pay to Study far from Home? Explaining the Returns to Geographic Mobility of Italian College Graduates. . mimeo.

Melitz, Marc, Ottaviano, Gianmarco, 2008. Market size, trade and productivity. Review of Economic Studies 75, 295-316.

Michelacci, Claudio, Silva, Olmo, 2007. Why so many local entrepreneurs? Review of Economics and Statistics 89, 615-633.

Mincer, Jacob, 1958. Investment in human capital and personal income distribution. Journal of Political Economy 66, 281-302.

Moomaw, Ronald L., 1983. Is population scale a worthless surrogate for business agglomeration economies? Regional Science and Urban Economics 15, 525-545.

Nocke, Volker, 2006. A gap for me: entrepreneurs and entry. Journal of European Economic Association 4, 929-956.

Poschke, Markus, 2008. Who becomes an entrepreneur? Labor market prospects and occupational choice. Discussion Paper No. 3816. IZA.

Putnam, Robert D., 1993. Making Democracy Work. Princeton University Press, Princeton.

Rajan, Rahuram, Zingales, Luigi, 1998. Financial dependence and growth. American Economic Review 88, 559-586.

Rice, Patricia, Venables, Tony, Patacchini, Eleonora, 2006. Spatial determinants of productivity: analysis for the regions of Great Britain. Regional Science and Urban Economics 36, 727-752.

Roback, Jennifer, 1982. Wages, rents and the quality of life. Journal of Political Economy 90, 1257-1278.

Rosenthal, Stuart S., Strange, William C., 2003. Geography, industrial organization, and agglomeration. Review of Economics and Statistics 85, 377-393.

Rosenthal, Stuart S., Strange, William C., 2004. Evidence on the nature and sources of agglomeration economies. In: Henderson, J.V., Thisse, J.F. (Eds.), Handbook of Urban and Regional Economics, vol. 4. Elsevier, Amsterdam, pp. 2119-2172.

Rosenthal, Stuart S., Strange, William C., 2008. The attenuation of human capital spillovers. Journal of Urban Economics 64, 373-389.

Silva, Olmo, 2007. The jack-of-all-trades entrepreneur: innate talent or acquired skill? Economic Letters 97, 118-123.

Torrini, Roberto, 2005. Cross-country differences in self-employment rates: the role of institutions. Labour Economics 12, 661-683.

Wheeler, Christopher H., 2001. Search, sorting, and urban agglomeration. Journal of Labor Economics 19, 879-899. 